INTERNATIONAL JOURNAL OF RESEARCHES IN BIOSCIENCES, AGRICULTURE AND TECHNOLOGY (c) VISHWASHANTI MULTIPURPOSE SOCIETY (Global Peace Multipurpose Society) R. No. MH-659/13(N) www.ijrbat.in

\title{
SEED BORNE FUNGI ASSOCIATED WITH SOME PULSES FROM GONDIA (MS)
}

\author{
Kawale M V, Borkar K M1 \& Tagade W Y2 \\ Dhote Bandhu Science College Gondia (MS) \\ 1 MB Patel College, Sakoli \\ 2 C.J. Patel College, Tirora \\ kawalemahesh@gmail.com
}

\begin{abstract}
:
Pulses are the second most important group of food plants belonging to family Fabaceae. They form an important source of dietary carbohydrates, proteins, essential amino acids and micronutrients such as calcium, phosphorus and iron. The 4 pulses like Pisum sativum, Vigna mungo, Cicer arietinum and Cajanus cajan are commonly cultivated in Gondia district are collected. Various seed-borne fungi affect these pulses. In our study, we tried to understand the diversity of fungi found on pulses varieties grown in our region. The study is conducted by two methods viz. moist paper blotter method and agar plate method. Data were recorded for seed germination percentage, percent fungal occurrence and major seed borne fungi, which were identified and quantified by using blotter test as recommended by ISTA (International Seed Testing Association). Fungi most frequently isolated and identified were Aspergillus sp., Alternaria sp., Fusarium sp., Mucor sp., Rhizopus sp., Curvularia sp., Trichoderma sp. \&Penicillium sp.
\end{abstract}

Keywords: Pisum sativum, Vigna mungo, Cicer arietinum, Cajanus cajan, Seed borne fungi \& Blotter test.

\section{INTRODUCTION:}

Seed is the most important input for crop production. Pathogen free healthy seed is urgently needed for desired plant populations and good harvest. Many plant pathogens are seed-borne, which can cause enormous crop losses; reduction in plant growth and productivity of crops (Kubiak and Korbas, 1999; Dawson and Bateman, 2001; Islam et al., 2009). Legume seeds have comparatively higher protein content than non-legume plant. The high protein content makes them desirable crops in agriculture. The seeds of legumes are second only to cereals as the most important source of food for humans and animals (National Academy of Sciences, 1979). All varieties of pulses are excellent source of easily digestible protein. But there are several factors which are responsible for their low production. Among them, diseases play an important role (Nine, 1986 and Pal, 1996). Numerous examples exist in literature for the international and national spread of plant diseases as a result of the importation of seeds that were infected or contaminated with pathogens (Agarwal, 1976). Seed-borne diseases have been found to affect the growth and productivity of crop plants (Kubiak and Korbas, 1999; Weber et al., 2001; Dawson and Bateman, 2001). Presence or absence of seed borne fungi on seed surface is one of the important aspects that determine the quality of seed.

The present investigation was undertaken to find out the seed borne fungi associated with the seeds of selected legumes. Considering the nutritional, agronomical and industrial value of pulses and yield of legumes, the present study aims to investigate seed-borne fungi associated with Pisum sativum, Vigna mungo, Cicer arietinum and Cajanus cajan.

\section{METHOD AND MATERIAL:}

Selection and Collection of seed material: Pulses Seed samples viz. Pea (Pisum sativum (L.), Blackgram (Vigna mungo (L), Chickpea (Cicer arietinum (L.) and Pigeonpea (Cajanus cajan (L.) were selected for experimental study and collected from different growers of Gondia (Maharashtra). Seed samples were bulked together and selected randomly for further investigations (Fig. 1).

Germination of Seeds: Study of germination percentage of above seeds was done by roll-towel 
technique (Muskett, 1948). The seed germination count was taken on sixth day of incubation. Seed germination data was recorded every month throughout the year.

Assessment of seed mycoflora: Isolation of fungi was done by both blotter as well as agar plate method as recommended by ISTA (1966). The seed samples were stored in small cotton bags under normal room temperature condition for one year. At the end of year 100 seeds were taken out randomly and incidence of fungi ware recorded. Total percentage of fungal incidence was calculated by using the formula suggested by Sahai and Mahrotra (1982).

Percent Fungal Occurrence $=$ Total no. of seeds in which particular fungus appeared $\times 100$ Total no. of seeds studied

\section{RESULTS AND DISCUSSION}

In the first part of our study, germination percentage of Pisum sativum, Vigna mungo, Cicer arietinum and Cajanus cajan was taken on monthly basis throughout the year. Our observations show that, in Pisum sativum, germination percentage was highest during the months of January to May 2016, lateron germination rate was decreased continuously. Same condition was observed in Vigna mungo and Cicer arietinum where higher germination percentage phase was between January to March, afterwards germination percentage came down. While in Cajanus cajan the percentage germination was decreased initially and increased towards the end i.e. in the month of November and December (Table 1).

After one year storage, all four seed samples were studied by both blotter as well as agar plate method for the type of fungal incidence. During the investigation seed mycoflora of different pulses viz. Pisum sativum, Vigna mungo, Cicer arietinum and Cajanus cajan, total 24 fungi were isolated. Recorded fungi were Alternaria alternata, Aspergillusflavus, Aspergillus fumigates, Aspergillus nidulans, Aspergillus niger, Aspergillus ochraceus, Aureobasidium sp., Chaetomium sp., Curvularia lunata, Fusarium oxysporum, Memnoniella sp.,
Penicillium chrysogenum, Penicillium multicolor, Penicillium notatum, Penicillium oxalicum, Phomalingum, Phytophthoraundulata, Pythium sp., Rhizopus nigricans, Syncephalastrum sp., \& Trichoderma viridae. All the 24 fungi were isolated from the seeds of Pisum sativum, 22 fungi were isolated from the seeds of Vigna mungo (Aspergillus ochraceus and Phytophthora undulate were absent) $\&$ Cicer arietinum (Aspergillus fumigates \& Penicillium multicolor were absent) while 20 seed mycoflora were isolated from the seeds of Cajanus cajan (Penicillium chrysogenum, Penicillium multicolor, Phytophthora undulate \& Pythium sp. were absent). The percent occurrence of Alternaria alternata, Fusarium oxysporum \& Curvularia lunata were highest in the seeds of Pisum sativum. In Vigna mungo, the Rhizopus nigricans, Curvularia lunata and Aspergillus niger were highest. In Cicer arietinum, Fusarium oxysporum, Penicillium notatum $\&$ Aspergillus niger were highest while in Cajanus cajan, Aspergillus niger, Rhizopus nigricans and Penicillium oxalicum were highest (Fig. 2 \& Plate 1).

\section{CONCLUSION:}

Seed-borne fungi have been found to affect the growth and productivity of crop plants. This must be addressed properly because high seed quality is essential in any crop production venture to attain higher yield and good quality products. In this study significant number of fungi was isolated from these seed samples. Seed borne mycoflora increases with the increase in storage period. The percentage of external infestation was more in comparison to internal infestation. Post harvest processing can be done and also the proper storage is needed.

\section{REFERANCE :}

Agrawal P. K. (1976): Identification of suitable seed storage places in India on the basis of temperature and relative humidity condition. Seed Res. 4(1):6-11.

Dawson W.A.J.M. and Bateman G.L. (2001): Bateman. Fungal communities on roots of wheat and barley and effects of seed 
treatments containing fluquinconazole applied to control take-all. Plant Pathology, 50: 5-82.

Dawson W.A.J.M. and Bateman G.L. (2001): Bateman. Fungal communities on roots of wheat and barley and effects of seed treatments containing fluquinconazole applied to control take-all. Plant Pathology, 50: 5-82.

International Seed Testing Association, (1966): International rules for seed testing. Int. Seed Test. Assn. 31: 1-157.

Islam S.M.M., Masum M. M. I. and Fakir M. G. A. (2009): Prevalence of seed-borne fungi in sorghum of different locations of Bangladesh. Scientific Research and Essay.4(3):175-179

Kubiak K. and Korbas M. (1999): Occurrence of fungal diseases on selected winter wheat cultivars. PostepyOchronieRoslin, 39 (2): 801 804

Muskett, A. E., (1948): Technique for the examination of seed for the presence of seed borne fungi. Trans. Br. Mycol. Soc., 30: 74-83.

National Academy of Sciences (1979): Genetic vulnerability of major crops. Washington, D C. Tropical legumes: resources for the future. Washington, DC.

Nine Y.L. (1986): Opportunities for research on diseases of pulse crops.Indian Phytopathology,.39(3):333-342.

Pal M. (1996): Pulse disease scenario. Indian Phytopathol.49 (2):129-131.

Sahai, A. and B. S. Mehrotra, (1982): Mycoflora associated with the seed of forest trees and train effect on germination. Proc. Ind. Nat. Sci. Acad. Part B. 48(5): 706-713.

Weber R. B., Hrynczuk B., RunowskaHrynczuk and Kita B (2001): Influence of the mode of tillage on diseases of culm base in some winter wheat varieties, oats, and spring wheat. $J$. Phytopathol. 149: 185-188. 

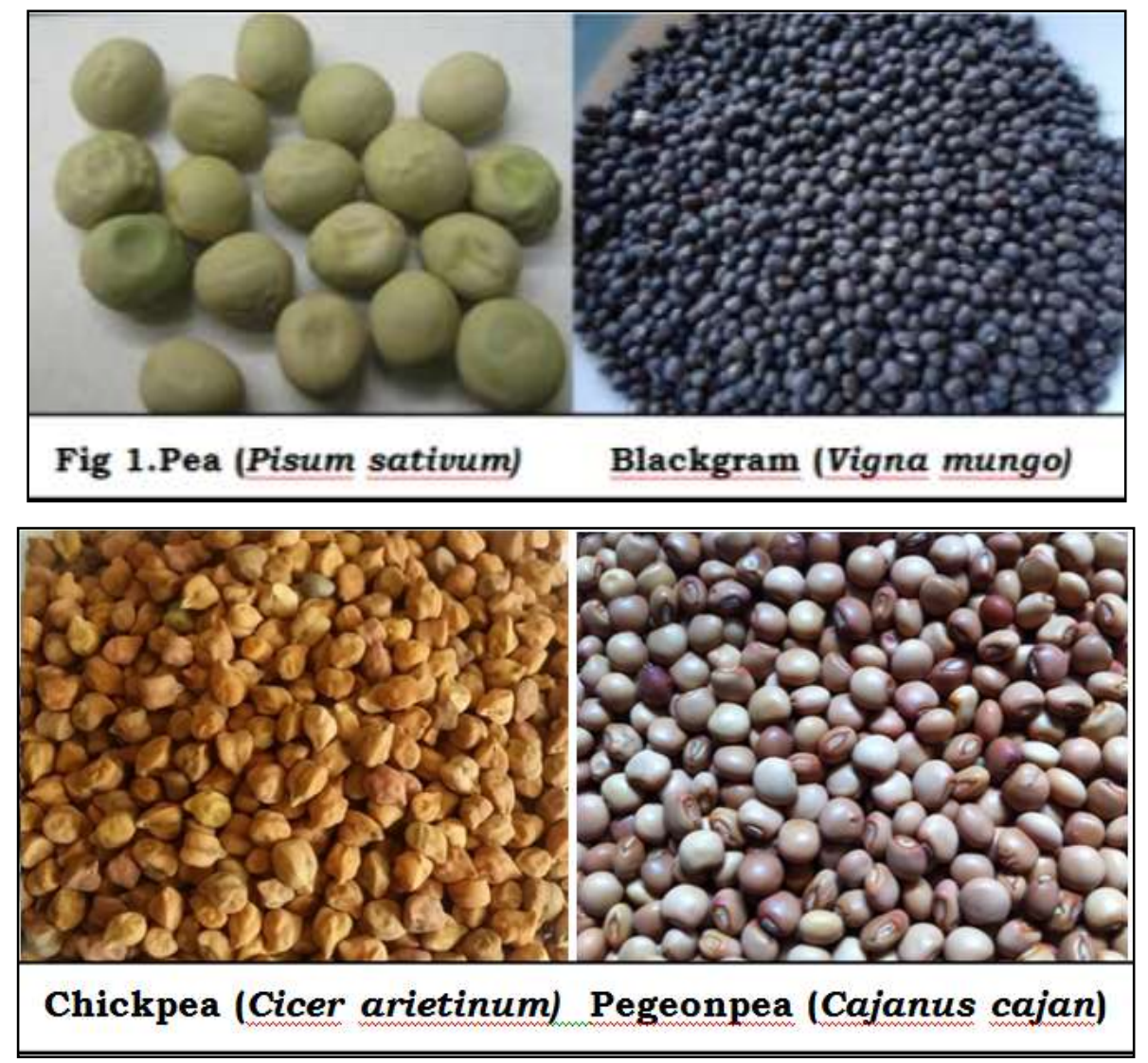
Table-1: Monthly germination percentage of different pulses.

\begin{tabular}{|c|c|c|c|c|c|}
\hline \multirow[b]{2}{*}{ S.N. } & \multirow[b]{2}{*}{ Months } & \multicolumn{4}{|c|}{ Germination \% different Pulses } \\
\hline & & Pisum sativum & Vigna mungo & Cicer arietinum & Cajanus cajan \\
\hline 1 & Jan-16 & 88.50 & 84.00 & 90.00 & 85.00 \\
\hline 2 & Feb-16 & 90.00 & 85.00 & 87.50 & 81.00 \\
\hline 3 & Mar-16 & 85.00 & 80.00 & 81.00 & 80.00 \\
\hline 4 & Apr-16 & 82.50 & 73.00 & 77.50 & 78.00 \\
\hline 5 & May-16 & 80.50 & 70.50 & 73.00 & 75.00 \\
\hline 6 & Jun-16 & 75.00 & 63.00 & 70.00 & 71.00 \\
\hline 7 & Jul-16 & 76.50 & 61.50 & 69.00 & 70.00 \\
\hline 8 & Aug-16 & 78.00 & 66.00 & 65.50 & 70.00 \\
\hline 9 & Sep-16 & 72.50 & 58.50 & 61.00 & 68.50 \\
\hline 10 & Oct-16 & 70.00 & 55.00 & 60.00 & 66.50 \\
\hline 11 & Nov-16 & 68.50 & 48.00 & 59.00 & 78.00 \\
\hline 12 & Dec-16 & 64.00 & 41.00 & 55.00 & 87.00 \\
\hline
\end{tabular}

Fig 2. Occurence of Seed Mycoflora in Different Pulses

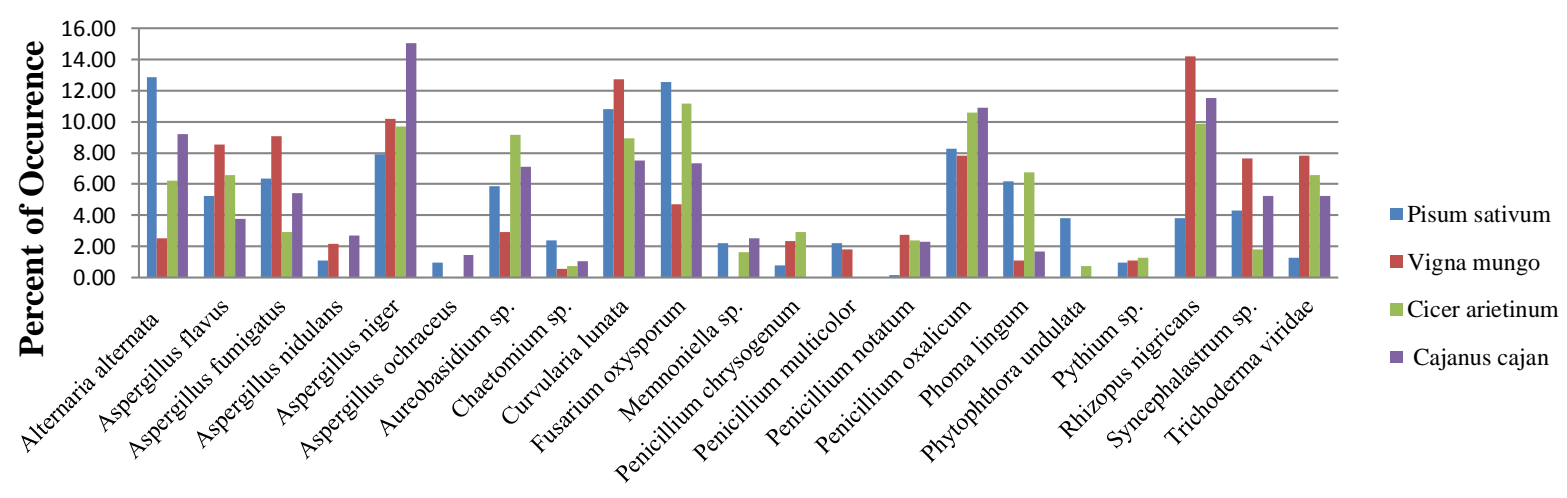

\section{Seed Mycoflora}


Plate:1. Microphotographs of Recorded fungal species from different pulses.

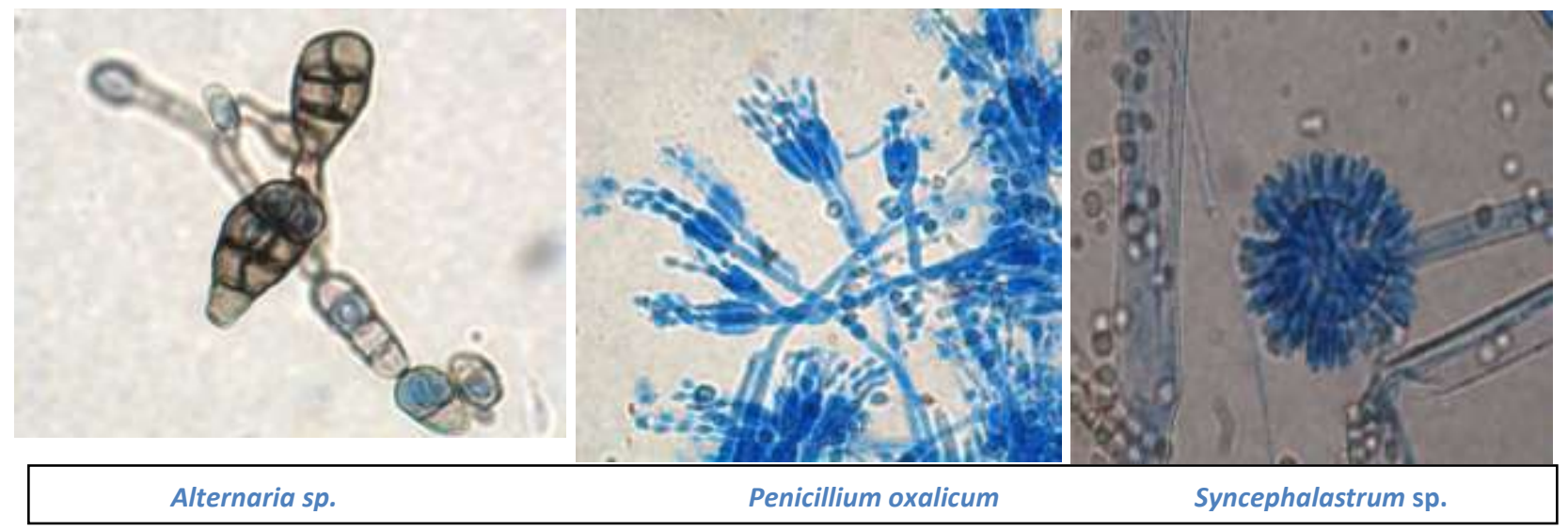

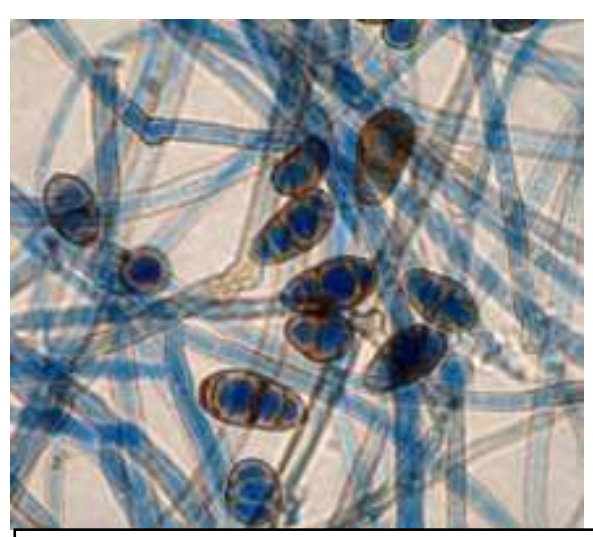

Curvularia lunata

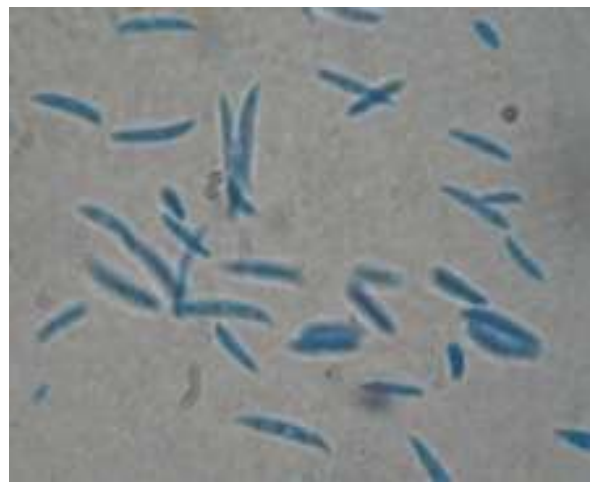

Fusarium oxysporum

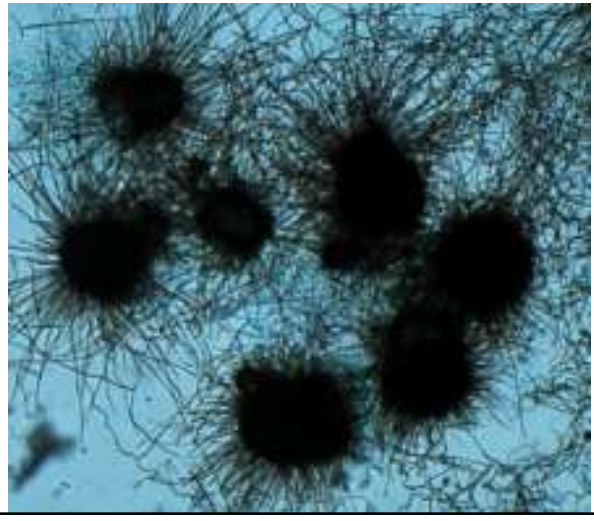

Phomasp.

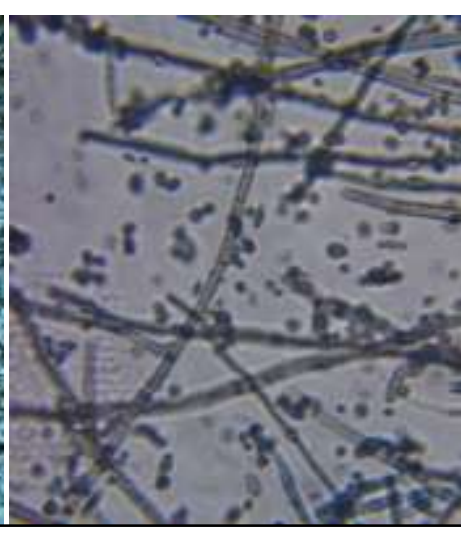

Aureobasidium sp.

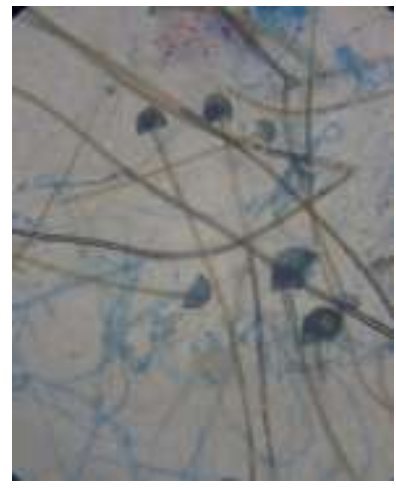

Rhizopus nigricans 